\title{
下顎両側大歯欠損症例における 小臼霜部咀嚼の筋電図的特徵
}

\author{
大井治正虫本栄子 三谷 春保
}

Electromyographic Features of Mastication Circumscribed within the Premolar Regions in the Cases of Bilateral Lower Molar Missing

Harumasa Ohi, Eiko Mushimoto and Haruyasu Mitani

\section{緒言}

両側大鼠歯の欠損を局部床義歯により補緅し，咬合接 触面積を回復することによって, 食塊形成や咀嚼が容易 となり ${ }^{1,2)}$, 咀嚼能率の増大 ${ }^{3,4)}$ や咀嚼運動経路の正常化 ${ }^{5}$ のみられることが知られている.

しかしながら，この種の久損状態の術前における咀嚼 の運動学的特徴については，まだ十分明らかではない.

本研究の目的は，下頡両側大臼歯欠損の補経による効 果と咀虂運動系への影響を検索するのに先だって，当該

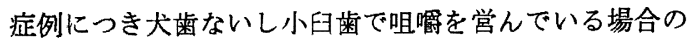
EMG 的特徴を検索することである.

\section{研究方法}

\section{1. 被検者}

被検者は咀嘫障害を主訴として本学付属病院に来院 し，下矤両側大鼠がすべて欠損しているいわゆる両側 性遊離端ケース (Kennedy の1級)で，小臼歯ないし犬 歯部で咀嚼する習慣をもつ患者 5 名 (男: 1 名，女 : 4 名，年㱓 39〜64 歳) である (Table 1). 上鿓は欠損が無 いか，あるいはあっても bridge で修復ずみであり，ま た下頡の欠損部以外の修復処置を終了し，1 1 月以上経 過している.

大阪歯科大学歯科補緅学第 3 集座 (主任 : 三谷春保教授) Osaka Dental University, The 3rd Dept. of Prosthodontics (Chief: Prof. Haruyasu Mitani) 昭和 59 年 12 月 25 日受付

\section{2. データの集積，記録および再生}

1) ピーナッッの粉砕能

ピーナッッの粉砕能の測定には, Manly と Braley

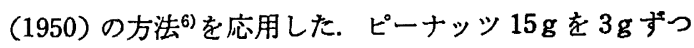

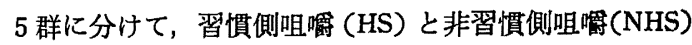
に分けて，随意にそれぞれ 20 回ずつ片側咀嗳させたの ち,ビーカーに回収し，10 mesh の篩 (Iida Seisakusho Co., Ltd. Osaka) 上に残留した試料を $100^{\circ} \mathrm{C}$ 乾燥器 中で 1 時間乾燥し, 電子天科 (SF-600, Shinko Denshi Co., Ltd.) で計量して $10 \mathrm{mesh}$ 節上残留量 (mg) をピ ーナッッ粉砕能のパラメータとみなした.

2) EMG

被検食品の種類や大きさが EMG の積分值に大きく影 響する7 9)ので, homogeneous な食品7として十分咬み 込んで軟化したガム (Dentyne chewing gum) 1 個を用 い，習慣側咀嚼と非習慣側咀嚼を行わせ，従来より教室 で行っている方法 ${ }^{10 \sim 17)}$ 亿従い，両側咬管浅部中央 $(\mathrm{Mm})$ および側頭笳後部 (Tp) から誘導した表面 EMG（三栄 測器社製生体電気増幅ユニット 1253 型) Tronics Research, Inc. Seattle) による切歯点の頸運動 動径とともにデータレコーダ（TEAC-SR 51）に同時記

Table 1 Subjects' presentation

\begin{tabular}{|c|c|c|c|c|c|}
\hline Subjects & Sex & $\begin{array}{c}\text { Age } \\
\text { in } \\
\text { years }\end{array}$ & $\begin{array}{c}\text { Missing } \\
\text { teeth }\end{array}$ & $\begin{array}{c}\text { Habitual } \\
\text { chewing } \\
\text { side }\end{array}$ & $\begin{array}{l}\text { Denture } \\
\text { wearing } \\
\text { period }\end{array}$ \\
\hline 1 & $\hat{\delta}$ & 64 & \begin{tabular}{l|l|}
76 & 67
\end{tabular} & $\mathrm{~L}$ & - \\
\hline 2 & 우 & 50 & \begin{tabular}{l|l}
7654 & 67 \\
\end{tabular} & $\mathrm{~L}$ & 18 months \\
\hline 3 & q & 39 & $7 6 5 \longdiv { 4 5 6 7 }$ & $\mathrm{R}$ & - \\
\hline 4 & 우 & 64 & \begin{tabular}{l|l}
76 & 67
\end{tabular} & $\mathrm{~L}$ & - \\
\hline 5 & 우 & 49 & $\overline{567}$ & R & - \\
\hline
\end{tabular}




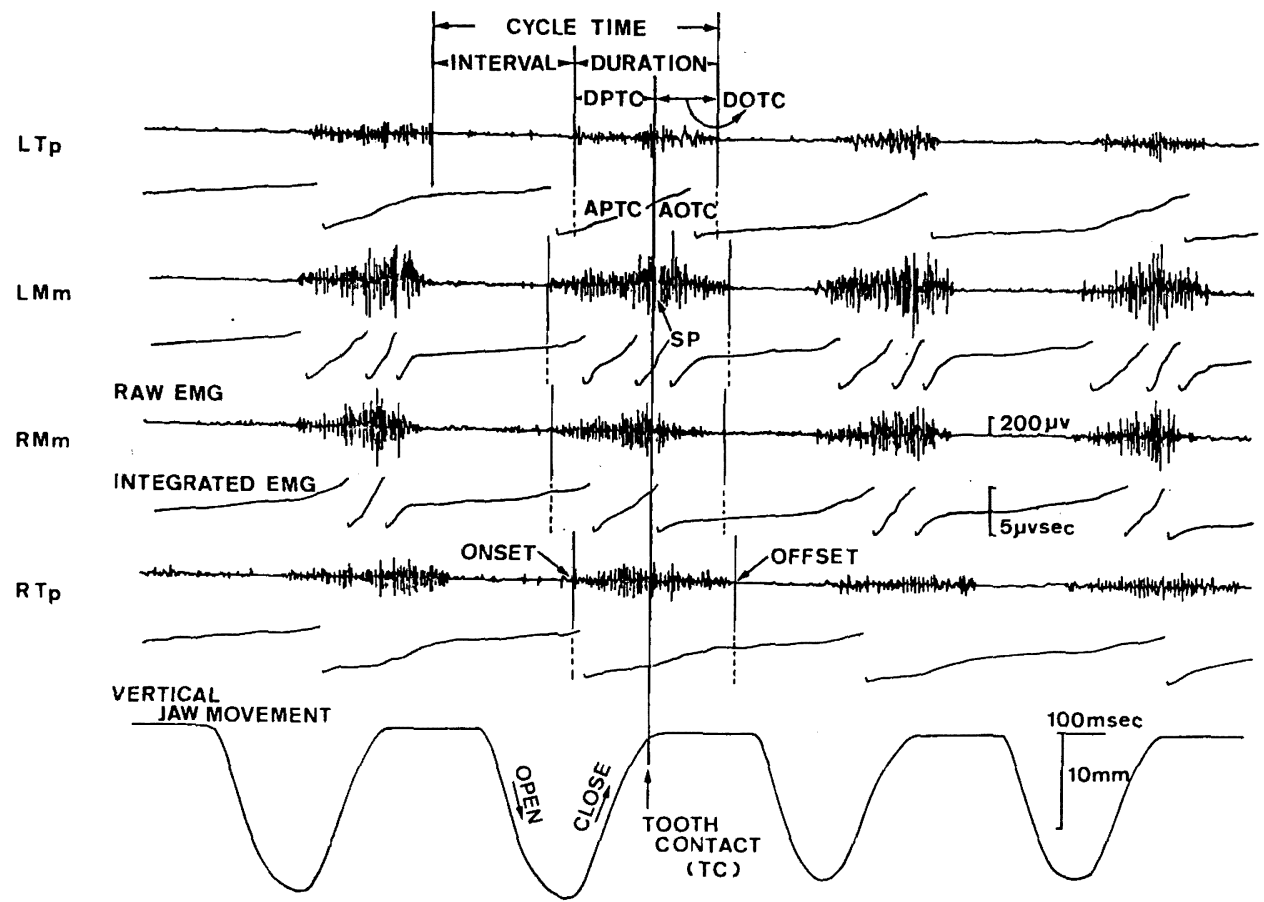

Fig. 1 Parameters measured on the strip record of EMG and MKG (vertical movement) DPTC : burst duration preceding tooth contact DOTC : burst duration outlasting tooth contact APTC : activity preceding tooth contact AOTC : activity outlasting tooth contact

録 $^{18,19)}$ した.

EMG は，原波形と積分オートリセット波形（三栄測 器社製積分ユニット 1322 型) として, MKG vertical 曲 線とともに電磁オシロペーパー上に $10 \mathrm{~cm} / \mathrm{sec}$ の紙送り 速度で再生（横河電機 Type 2924）した (Fig. 1).

\section{EMG データの計測}

再生した EMG 波形は, silent period (SP) と MKG の vertical 曲線を参考にして歯牙接触時点 (TC) を求 め, 各 burst を前後に 2 分して manual 法により計測し た以下のパラメータについて，ガム咀緭末期の連 続 20 ストロークの平均值および CV 值を代表值とした（Fig. 1).

a. EMG の時間的要素

DPTC

DOTC

duration (DPTC+DOTC)

interval

cycle time (duration+interval) b. burst 当りの EMG 積分值 ( $\mu$ vsec)

APTC

AOTC

APTC+AOTC

AOTC/APTC ratio

\section{4. データの分析}

データは分散分析法により, 主変動因子として被検者 I $(i)$, 咀嚼側 C $(k)$, を設定し, EMG ではさらに被検筋 $\mathrm{M}(j)$ を加え, これらがデータの変動に及ぼす主効果お よびそれらの交互作用効果について下記の linear model に従って解析した.

Total amount of peanuts remaining on 10 -mesh screen

$\mathrm{Y}=\mu+\mathrm{I}(i)+\mathrm{C}(k)+\mathrm{I} \times \mathrm{C}+\mathrm{e}$

EMG

$$
\begin{aligned}
& \mathrm{Y}=\mu+\mathrm{I}(i)+\mathrm{M}(j)+\mathrm{e}_{1}+\mathrm{C}(k)+\cdots \cdots+\mathrm{e}_{2} \\
& \mathrm{Y}: \text { mean } \\
& \mu: \text { general level }
\end{aligned}
$$


Table 2 Results of the analysis of variance (ANOVAR) for total amount of peanuts remaining on 10 -mesh screen

\begin{tabular}{|c|c|c|c|c|c|c|}
\hline SV & SS & df & MS & F & $\mathrm{p}$ & $\rho(\%)$ \\
\hline Individuals ( I ) & 11169772.32 & 4 & 2792443.08 & 97.78 & $<0.001$ & 67.37 \\
\hline Chewing sides (C) & 2514627.38 & 1 & 2514627.38 & 88.05 & $<0.001$ & 15.15 \\
\hline $\mathrm{C} \times \mathrm{I}$ & 1583227.12 & 4 & 395806.78 & 13.86 & $<0.001$ & 8.95 \\
\hline error & 1142368.80 & 40 & 28559.22 & & & 8.53 \\
\hline total & 16409995.62 & 49 & & & & 100.00 \\
\hline
\end{tabular}

SV : source of variation, SS : sum of squares, df : degree of freedom, MS : mean of square, $F:$ variance ratio ( $F$ values), $p:$ probability of the null hypothesis ( $p$ values), $\rho:$ effects of the variations in per cent

Table 3 Means and confidence limits at $95 \%$ level of total amount of peanuts remaining on 10 -mesh screen

\begin{tabular}{|c|c|c|c|c|c|c|}
\hline \multirow{2}{*}{ Chewing sides (C) } & \multicolumn{5}{|c|}{ Individuals ( I ) } & \multirow{2}{*}{ means } \\
\hline & $I_{1}$ & $\mathrm{I}_{2}$ & $\mathrm{I}_{3}$ & $I_{4}$ & I 5 & \\
\hline NHS & 1353.0 & 2669.4 & 2729.0 & 1518.2 & 2358.0 & 2125.5 \\
\hline HS & 1246.4 & 1703.8 & 2451.8 & 1403.0 & 1580.0 & 1677.0 \\
\hline means & 1299.7 & 2186.6 & 2590.4 & 1460.6 & 1969.0 & 1901.3 \\
\hline
\end{tabular}

$$
\begin{aligned}
& \text { I : Individuals }(i=1 \sim 5) \\
& \mathrm{M}: \text { Muscles }(j=1 \sim 4) \\
& \mathrm{C}: \text { Chewing sides }(k=1 \sim 2) \\
& \mathrm{e}: \text { error }
\end{aligned}
$$

\section{研究成綪}

\section{1. 個人差と咀嚼側差について}

本研究の被検者（Table 1) の一部が大臼歯のみでな く小臼歯欠損を含むものであり，また必ずしも左右側の 欠損歯数が同数でないことから，まず咀噮の難易度に関 して被検者別，および咀噮側別に検討した。 なお, Table 1 に示すように欠損歯数に左右差のある被検者では，常 に欠損歯数の少ない側が習慣性咀嚼側となっていた.

1) ピーナッッ粉砕能

ピーナッッ咀嚼試験の結果では, 被検者間 I $(\mathrm{p}<$ $0.001)$, 咀嚼側間 $C(p<0.001)$ およびそれらの交互作 用 $\mathrm{C} \times \mathrm{I}(\mathrm{p}<0.001)$ に有意性を認め (Table 2), 小臼歯 欠損をむ伴うケース (Subj. 2, 3,5の NHS と Subj. 3 の HS）で大きい残留量を示し，特に第 2 小臼歯の有無は食 品の粉砕能に強く影響を及ぼした. また左右の残存歯数 の異なる被検者 2,3,5 では, 残存歯数の多い側 (HS) で 有意に小さい値を示したが, 残存歯数に差のない被検者

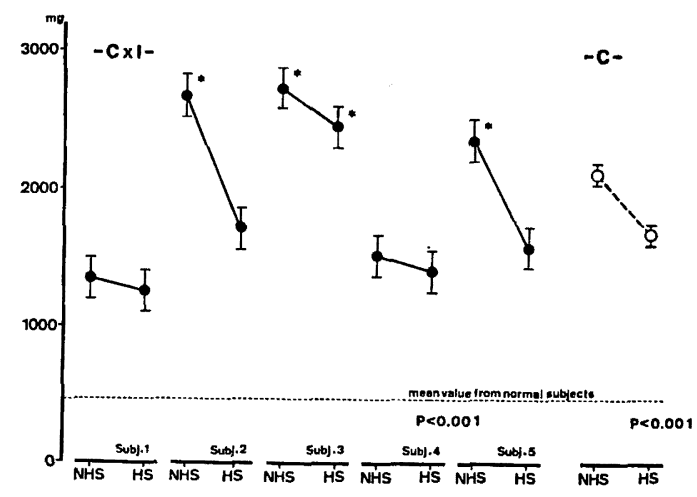

Fig. 2 Total amount of peanuts remaining on 10-mesh screen. Significant interaction $(\mathrm{C} \times \mathrm{I})$ and interchewing side (C) difference in Table 2 are illust. rated. Vertical bars show $95 \%$ confidence interval NHS : non-habitual-sided chewing, HS : habitualsided chewing

1, 4 では，有意差は認められなかった (Table 2, 3, Fig. 2).

2) EMG cycle time

EMG による cycle time の計測值では個人差がめだ ち，またすべての被検者で咀嚼側間に有意差を認め，特 に第 1 小四歯以後が久損している被検者 2 の NHS（右 
Table 4 ANOVAR for EMG cycle time

\begin{tabular}{l|rrrrrr}
\hline \multicolumn{1}{c|}{ SV } & \multicolumn{1}{c}{ SS } & df & \multicolumn{1}{c}{ MS } & $F^{\prime}$ & p $^{\prime}$ & $\rho^{\prime}(\%)$ \\
\hline Individuals ( I ) & 346228.8872 & 4 & 86557.2218 & 10969.8019 & $<0.001$ & 82.74 \\
Muscles (M) & $(4.2765)$ & $(3)$ & $(1.4255)$ & & & \\
error1 & $(115.1423)$ & $(12)$ & $(9.5952)$ & & & \\
Chewing sides (C) & 11978.5210 & 1 & 11978.5210 & 1518.0940 & $<0.001$ & 2.86 \\
C $\times$ I & 59951.7765 & 4 & 14987.9441 & 1899.4923 & $<0.001$ & 14.32 \\
C $\times$ M & $(17.6255)$ & $(3)$ & $(5.8752)$ & & & \\
error2 & $(99.6720)$ & $(12)$ & $(8.3060)$ & & & \\
error2 & 236.7163 & 30 & 7.8905 & & & 0.08 \\
\hline \multicolumn{1}{c}{ total } & 418395.9010 & 39 & & & 100.00 \\
\hline
\end{tabular}

error' : pooled error

Table 5 Means and confidence limits at 95\% level of EMG cycle time

\begin{tabular}{c|cccccc|c}
\hline \hline \multirow{2}{*}{ Chewing sides (C) } & \multicolumn{6}{|c|}{ Individuals ( I ) } & \multirow{2}{*}{ means } \\
& $\mathrm{I}_{1}$ & $\mathrm{I}_{2}$ & $\mathrm{I}_{3}$ & $\mathrm{I}_{4}$ & $\mathrm{I}_{5}$ & \\
\hline NHS & 626.49 & 818.78 & 733.06 & 773.91 & 835.09 & 757.47 \\
$\mathrm{HS}$ & 532.58 & 666.91 & 719.74 & 806.85 & 888.20 & 722.86 \\
\hline means & 579.53 & 742.84 & 726.40 & 790.38 & 861.64 & 740.16 \\
\hline \multicolumn{2}{l}{ Confidence limis at $95 \%$} & $\overline{\mathrm{I}_{i}}: \pm 2.03$ & $\overline{\mathrm{C}_{k}}: \pm 1.28$ & $\overline{\mathrm{C}_{k} \mathrm{I}_{i}}: \pm 2.87$ & (msec)
\end{tabular}

Table 6 ANOVAR for CV of EMG cycle time

\begin{tabular}{l|cccccr}
\hline \multicolumn{1}{c|}{ SV } & SS & df & MS & $F^{\prime}$ & $p^{\prime}$ & $\rho^{\prime}(\%)$ \\
\hline Individuals ( I ) & 112.8473 & 4 & 28.2118 & 45.4153 & $<0.001$ & 43.52 \\
Muscles (M) & $(1.6688)$ & $(3)$ & $(0.5563)$ & & & \\
error1 & $(8.8342)$ & $(12)$ & $(0.7362)$ & & & \\
Chewing sides (C) & 5.3722 & 1 & 5.3722 & 8.6481 & $<0.01$ & 1.87 \\
$\mathrm{C} \times \mathrm{I}$ & 115.8886 & 4 & 28.9722 & 46.6393 & $<0.001$ & 44.72 \\
$\mathrm{C} \times \mathrm{M}$ & 2.7190 & 3 & 0.9063 & 1.4590 & & 0.34 \\
error2 & $(6.2693)$ & $(12)$ & $(0.5224)$ & & & \\
error2 & 16.7723 & 27 & 0.6212 & & & 9.55 \\
\hline \multicolumn{1}{c}{ total } & 253.5994 & 39 & & & 100.00 \\
\hline
\end{tabular}

側）では著しく延長して，明らかに咀緭の困難性を示し た. 被検者 4,5 の cycle time は逆に HS が NHS より 延長し, CV 值も高くて, EMG cycle time が必ずしも咀 哷の難易度と一致するとはいえない結果を得た（Table 4〜7, Fig. 3, 4).

CV 值に関しても同様の傾向であった (Fig. 4).

\section{3) EMG 積分值}

1 burst 当りの積分値 APTC+AOTC $(p<0.025)$ と 歯牙接触時点で 2 分した burst 後半部 AOTC $(\mathrm{p}<0.01)$ は HS で有意に大きく, burst 前半部 APTC には有意性
はないものの危険率 $10 \%$ 以下で HS が優勢であった (Table 8〜13, Fig. 5).

Fig. 6 は個人別の APTC+AOTC の power coordination pattern を示しているが, 小臼歯がすべて残存して いて, 中心咬合位の安定している被検者 1 と, 検查以前 に義歯装着経験の長い被検者 2 では, HS, NHS ともに WMm 最優勢であり，ついで BMm が優勢という M-m type 20,21) の正常パターン22)を示した. 一方, 被検者 3, 4, 5 は MKG 的にも中心咬合位が不安定であり, 被検者 5 の NHS 以外は Tp の優勢がめだった. すなわち, 両 
Table 7 Means and confidence limits at $95 \%$ level of CV of EMG cycle time

\begin{tabular}{c|rrrrr|c}
\hline \hline \multirow{2}{*}{ Chewing sicles (C) } & \multicolumn{7}{|c|}{ Individuals } & (I) & \multirow{2}{*}{ means } \\
& $\mathrm{I}_{1}$ & $\mathrm{I}_{2}$ & $\mathrm{I}_{3}$ & $\mathrm{I}_{4}$ & $\mathrm{I}_{5}$ & \\
\hline NHS & 5.63 & 14.01 & 10.13 & 8.36 & 8.13 & 9.25 \\
HS & 5.70 & 6.85 & 9.46 & 10.87 & 9.71 & 8.52 \\
\hline means & 5.67 & 10.43 & 9.80 & 9.62 & 8.92 & 8.89 \\
\hline Confidence limits at $95 \%$ & $\overline{\mathrm{I}_{i}}: \pm 0.57$ & $\overline{\mathrm{C}_{k}}: \pm 0.36$ & $\overline{\mathrm{C}_{k} \mathrm{I}_{i}}: \pm 0.81$ & $(\%)$
\end{tabular}

Table 8 ANOVAR for APTC+AOTC

\begin{tabular}{l|rrrrrr}
\hline \multicolumn{1}{c|}{$\mathrm{SV}$} & $\mathrm{SS}$ & $\mathrm{df}$ & $\mathrm{MS}$ & $\mathrm{F}^{\prime}$ & $\mathrm{p}^{\prime}$ & $\rho^{\prime}(\%)$ \\
\hline Individuals (I) & 80.4868 & 4 & 20.1202 & 2.3000 & & 9.39 \\
Muscles (M) & 78.3128 & 3 & 26.1043 & 2.9842 & $<0.05$ & 10.75 \\
error1 & $(169.1667)$ & $(12)$ & $(14.0972)$ & & & \\
Chewing sides (C) & 54.4406 & 1 & 54.4406 & 6.2235 & $<0.025$ & 9.43 \\
$\mathrm{C} \times \mathrm{I}$ & $(9.8975)$ & $(4)$ & $(2.4744)$ & & & \\
$\mathrm{C} \times \mathrm{M}$ & $(23.7958)$ & $(3)$ & $(7.9319)$ & & & \\
error2 & $(68.3169)$ & $(12)$ & $(5.6931)$ & & & \\
error2' & 271.1769 & 31 & 8.747 & & & \\
\hline \multicolumn{1}{c}{ total } & 484.4109 & 39 & & & & 100.00 \\
\hline
\end{tabular}

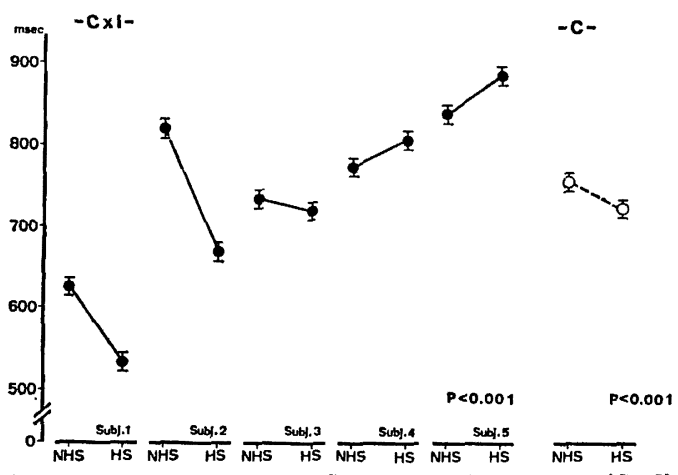

Fig. 3 EMG cycle time. Significant interaction $(\mathrm{C} \times \mathrm{I})$ and inter-chewing side (C) difference in Table 4 are illustrated

側大曰歯欠損患者の 4 筋 power coordination pattern は正常型からやや異常型23,24)にわたって広く分布してい た.

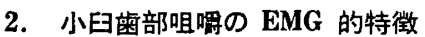

上述の結果をふまえて，小臼歯部咀霹の EMG 的特徴 について検討した.

1) burst duration

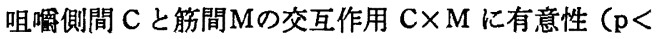

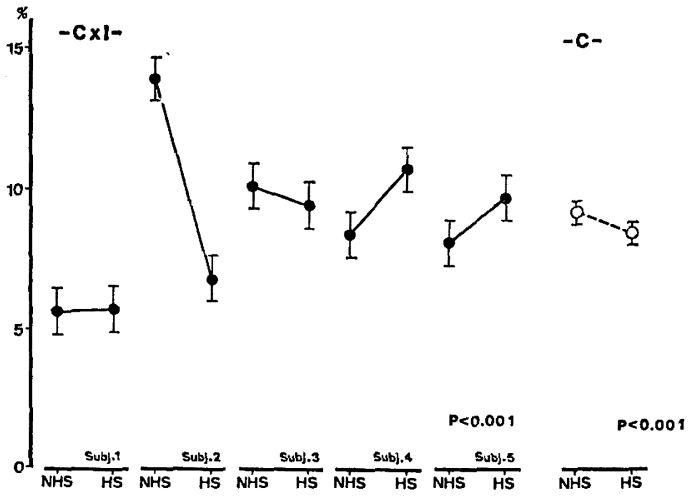

Fig. $4 \mathrm{CV}$ of EMG cycle time. Significant interaction $(\mathrm{C} \times \mathrm{I})$ and inter-chewing side (C) difference in Table 6 are illustrated

0.025）を認め, NHS の WMm が他の 3 筋よりも有意に 延長したのに対して, HS では BTp が他の 3 筋に比べて 有意に短い值を示した. そのため, NHS では両側の Mm 間に差があり，HS では両側 Tp 間に差が現れるという 異なった特徴のある time coordination patternを示 す結果を得た (Table 14, 15, Fig. 7).

$\mathrm{CV}$ 值に関しては，被検者間 I を除いて筋間 $\mathrm{M}(\mathrm{p}<$ 0.05）のみに有意性があり，咀嘌側と対側のいずれの側 でも Tp は Mmより有意に大きい分散值を示した 
Table 9 ANOVAR for APTC

\begin{tabular}{l|rrrrrr}
\hline \multicolumn{1}{c|}{ SV } & SS & df & MS & $F^{\prime}$ & $p^{\prime}$ & $\rho^{\prime}(\%)$ \\
\hline Individuals (I) & $(14.1828)$ & $(4)$ & $(3.5457)$ & & & \\
Muscles (M) & 63.6194 & 3 & 21.2065 & 5.4071 & $<0.01$ & 22.81 \\
error1 & $(76.3293)$ & $(12)$ & $(6.3608)$ & & & \\
Chewing sides (C) & 14.1455 & 1 & 14.1455 & 3.6068 & $(0.05<\mathrm{p}<0.1)$ & 4.50 \\
C $\times$ I & $(2.7457)$ & $(4)$ & $(0.6864)$ & & & \\
C $\times$ M & 24.0970 & 3 & 8.0323 & 2.0481 & & 5.42 \\
error2 & $(32.2444)$ & $(12)$ & $(2.6870)$ & & & \\
error2 & 125.5023 & 32 & 3.9219 & & & 67.27 \\
\hline \multicolumn{1}{c}{ total } & 227.3642 & 39 & & & 100.00 \\
\hline
\end{tabular}

Table 10 ANOVAR for AOTC

\begin{tabular}{|c|c|c|c|c|c|c|}
\hline SV & SS & df & MS & $\mathrm{F}^{\prime}$ & $\mathbf{p}^{\prime}$ & $\rho^{\prime}(\%)$ \\
\hline Individuals (I) & 37.7536 & 4 & 9.4384 & 3.6648 & $<0.05$ & 27.98 \\
\hline Muscles (M) & 21.4123 & 3 & 7.1374 & 2.7714 & $(0.05<p<0.1)$ & 15.40 \\
\hline error 1 & 30.9051 & 12 & 2.5754 & 3.0816 & $<0.05$ & 17.28 \\
\hline Chewing sides (C) & 13.0805 & 1 & 13.0805 & 16.4146 & $<0.01$ & 9.94 \\
\hline $\mathrm{C} \times \mathrm{I}$ & 8.4305 & 4 & 2.1076 & 2.6448 & & 4.24 \\
\hline $\mathrm{C} \times \mathrm{M}$ & $(1.9243)$ & 3 & $(0.6414)$ & & & \\
\hline error2 & $(10.0289)$ & 12 & $(0.8357)$ & & & \\
\hline error ${ }^{\prime}$ & 11.9532 & 15 & 0.7969 & & & 25.16 \\
\hline total & 123.5352 & 39 & & & & 100.00 \\
\hline
\end{tabular}

Table 11 Means and confidence limits at 95\% level of APTC+ AOTC

\begin{tabular}{l|cccc|c}
\hline \hline \multirow{2}{*}{$\begin{array}{c}\text { Chewing } \\
\text { sides (C) }\end{array}$} & WTp & WMm & BMm & BTp & means \\
\hline NHS & 5.83 & 8.69 & 4.15 & 5.82 & 6.12 \\
HS & 10.19 & 9.75 & 7.43 & 6.46 & 8.46 \\
\hline means & 8.01 & 9.22 & 5.79 & 6.14 & 7.29 \\
\hline Confidence limit at $95 \%$ & $\overline{\mathrm{M}}_{j}: \pm 1.91$ & $\overline{\mathrm{C}}_{k}: \pm 1.35$ \\
$(\mu \mathrm{vsec})$
\end{tabular}

Table 12 Means and confidence limits at $95 \%$ level of APTC

\begin{tabular}{l|cccc|c}
\hline \hline $\begin{array}{l}\text { Chewing } \\
\text { sides (C) }\end{array}$ & WTp & WMm & BMm & BTp & means \\
\hline NHS & 3.93 & 5.75 & 2.90 & 3.11 & 3.92 \\
HS & 6.71 & 6.14 & 5.45 & 2.15 & 5.11 \\
\hline means & 5.32 & 5.95 & 4.17 & 2.63 & 4.52 \\
\hline \multicolumn{7}{l}{ Confidence limit at $95 \%$} & $\overline{\mathrm{M}}_{j}: \pm 1.28$ & ( $\mu \mathrm{vsec})$
\end{tabular}

Table 13 Means and confidence limits at $95 \%$ level of AOTC

\begin{tabular}{|c|c|c|c|c|c|}
\hline \multirow{2}{*}{$\begin{array}{l}\text { Chewing } \\
\text { sides (C) }\end{array}$} & \multicolumn{4}{|c|}{ Muscles (M) } & \multirow{2}{*}{ means } \\
\hline & WTp & $\mathrm{WMm}$ & $\mathrm{BMm}$ & BTp & \\
\hline NHS & 1.90 & 2.94 & 1.25 & 2.71 & 2.20 \\
\hline HS & 3.48 & 3.61 & 1.98 & 4.30 & 3.34 \\
\hline means & 2.69 & 3.27 & 1.61 & 3.51 & 2.77 \\
\hline
\end{tabular}

(Table 16, 17, Fig. 8).

2) DPTC

歯牙接触までの burst 前半部の持続時間 DPTCに関 ᄂ, 咀嚼側間 C と筋間Mの交互作用に有意性 $(p<0.001)$ を認めた. 本パラメータを onset time の同期性の指標 としてみることができる. すなわち, NHS では BTp の onset time がやや遅れて咬筋先行型の傾向を示すものの 4 筋の同期性はむしろ高く, 一方 HS では BTp の onset time が他の 3 筋よりも有意に遅れ, grinding type ${ }^{25)}$ と みられる特徴を示したが, 他の 3 筋間の同期性は高かっ 
$114-640$

た (Table 18, 19, Fig. 9).

3) DOTC

DOTC は歯牙接触から burst の offset までの持続時 間である. この場合, 咀礵側による差はなく，筋間Mに 有意性 $(\mathrm{p}<0.01)$ がみられ，BTp の有意の延長，すなわ ち offset の遅延がみられた (Table 20，21，Fig. 10).

\section{4) EMG 積分値}

APTC+AOTC, APTC および AOTC に関して, そ の power coordination pattern Fig. 11 に示した. $\mathrm{APTC}+\operatorname{AOTC}(\mathrm{p}<0.05)$ と APTC $(\mathrm{p}<0.01)$ で筋間 に有意差があり，作業側 2 筋が非作業側 2 筋よりも有意 に大きいが, WMm 優勢の正常パターン ${ }^{22)}$ はやや不明瞭 である (Table 8〜13, Fig. 11).

5) APTC/AOTC ratio

APTC および AOTC 単独では，咀喵側間 C と筋間M の交互作用 $\mathrm{C} \times \mathrm{M}$ に有意性はなかったが, AOTC/APTC
29 巻 3 号 (1985)

ratio に関しては, $\mathrm{C} \times \mathrm{M}$ に有意性 $(\mathrm{p}<0.01)$ を認め， HS の BTp に拈いて有意に高い值がみられ，これに対

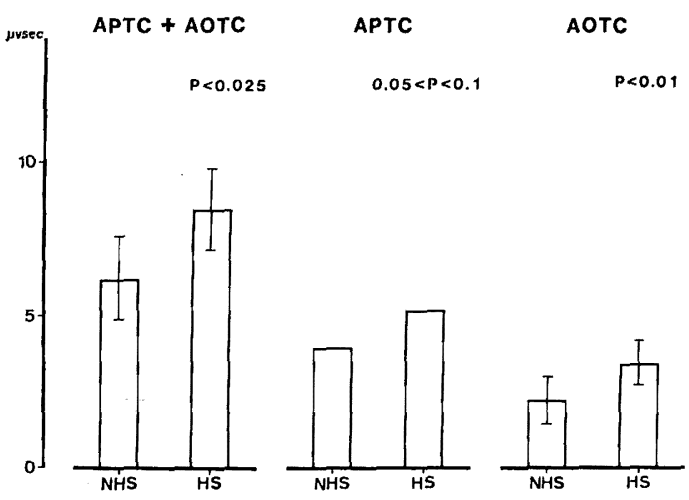

Fig. 5 Integrated EMG activities ( $\mu_{\mathrm{vsec}}$ ). APTC + AOTC (left), APTC (middle), AOTC (right). Significa nt inter-chewing side (C) difference in Table 8 and 10 are illustrated.
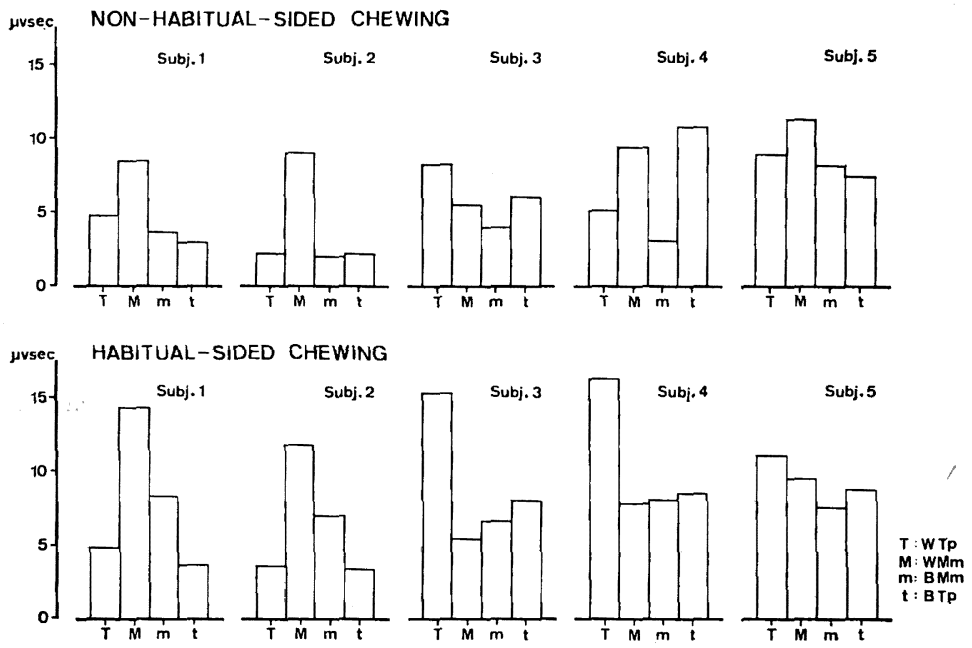

Fig. 6 EMG power coordination patterns (APTC+AOTC) in each subject

Table 14 ANOVAR for EMG burst duration

\begin{tabular}{l|rrrrrr}
\hline \multicolumn{1}{c|}{ SV } & \multicolumn{1}{c}{ SS } & df & MS & \multicolumn{1}{c}{ F } & p & $\rho(\%)$ \\
\hline Individuals ( I ) & 63280.6119 & 4 & 15820.1530 & 12.2241 & $<0.001$ & 53.27 \\
Muscles (M) & 12910.2945 & 3 & 4303.4315 & 3.3252 & & 10.34 \\
error1 & 15530.1761 & 12 & 1294.1813 & 4.5873 & $<0.01$ & 10.41 \\
Chewing sides (C) & 3775.2490 & 1 & 3775.2490 & 13.3815 & $<0.01$ & 2.99 \\
$\mathrm{C} \times$ I & 13354.9154 & 4 & 3338.7288 & 11.8342 & $<0.001$ & 10.48 \\
$\mathrm{C} \times \mathrm{M}$ & 4427.1965 & 3 & 1475.7322 & 5.2308 & $<0.025$ & 3.07 \\
error2 & 3385.5066 & 12 & 282.1256 & & & 9.44 \\
\hline \multicolumn{1}{c}{ total } & 116663.9500 & 39 & & & & 100.00 \\
\hline
\end{tabular}


して NHS では筋間に有意差が認められなかった（Table 22, 23, Fig. 12).

\section{考察}

\section{1. 研究方法について}

本研究の目的は，下顥両側大曰歯欠損患者におりる犬 齿ないし小臼歯部咀嚼の運動学的特徴を検索することで

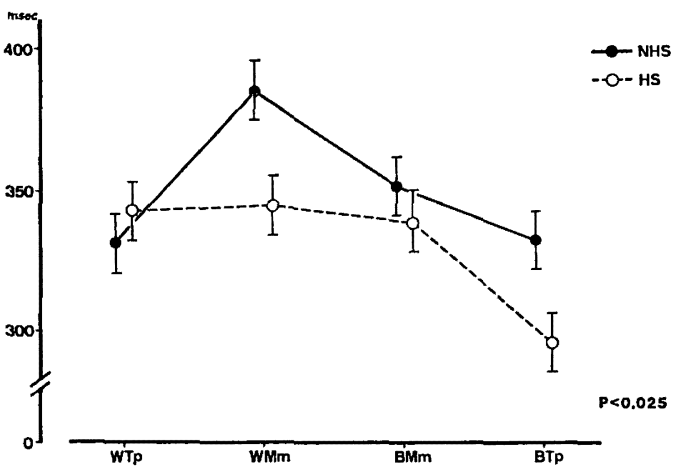

Fig. 7 EMG burst duration. Significant interaction $(\mathrm{C} \times \mathrm{M})$ in Table 14 is illustrated

Table 15 Means and confidence limits at $95 \%$ level of EMG burst duration

\begin{tabular}{c|cccc|c}
\hline \hline \multirow{2}{*}{$\begin{array}{c}\text { Chewing } \\
\text { sides (S) }\end{array}$} & WTp & Wuscles (M) & \multirow{2}{*}{ WMm } & BTp & \\
\hline NHS & 331.52 & 385.35 & 352.39 & 333.60 & 350.72 \\
HS & 343.84 & 345.33 & 339.14 & 296.83 & 331.29 \\
\hline means & 337.68 & 365.34 & 345.77 & 315.22 & 341.00 \\
\hline
\end{tabular}

Confidence limit at $95 \% \quad \overline{\mathrm{C}_{k}}: \pm 6.69 \quad \overline{\mathrm{C}_{k} \mathrm{I}_{i}}: 10.58$ (msec)
あり，その一環として咀嚼の難易度の示標として簡便か つ明確なピーナッツ咀嚼試験法を用いた。通常のピーナ ッツ咀嚼試験では, 咀嚼値ないし咀嚼能率を算出してい るが, 本研究では個人差と咀嚼側差が大きく，ピーナッ ツ回収量の対照值を定めにくかったため, 10 mesh 篩上

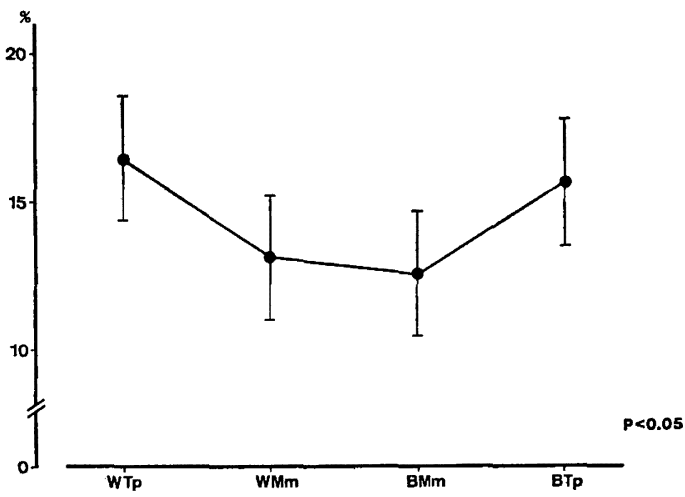

Fig. $8 \mathrm{CV}$ of burst duration. Significant inter-muscle (M) differences in Table 16 are illustrated

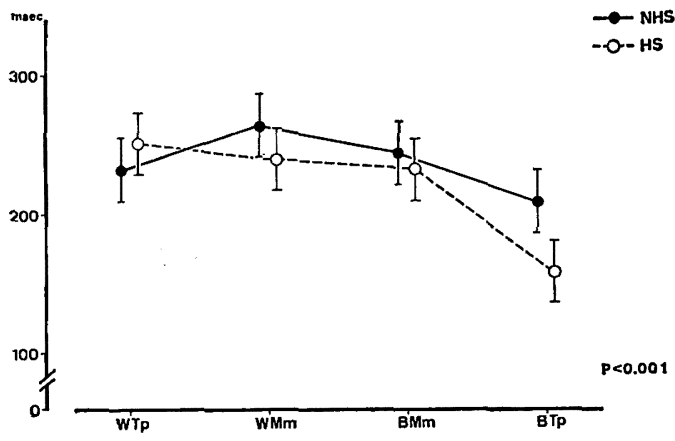

Fig. 9 DPTC. Significant interaction $(C \times M)$ in Table 18 is illustrated

Table 16 ANOVAR for $\mathrm{CV}$ of burst duration

\begin{tabular}{l|cccccc}
\hline \multicolumn{1}{c|}{ SV } & SS & df & MS & $F^{\prime}$ & $\mathrm{p}^{\prime}$ & $\rho^{\prime}(\%)$ \\
\hline Individuals ( I ) & 313.7171 & 4 & 78.4293 & 6.9253 & $<0.001$ & 31.40 \\
Muscles (M) & 107.7279 & 3 & 35.9093 & 3.1708 & $<0.05$ & 8.63 \\
error1 & $(186.6439)$ & $(12)$ & $(15.5539)$ & & & \\
Chewing sides (C) & $(4.7645)$ & $(1)$ & $(4.7645)$ & & & \\
$\mathrm{C} \times \mathrm{I}$ & 116.2662 & 4 & 29.0666 & 2.5666 & & \\
$\mathrm{C} \times \mathrm{M}$ & $(6.8553)$ & $(3)$ & $(2.2851)$ & & & \\
error2 & $(118.8313)$ & $(12)$ & $(9.9026)$ & & & \\
error2 & 317.0975 & 28 & 11.3249 & & & 100.00 \\
\hline \multicolumn{1}{c}{ total } & 854.8088 & 39 & & & \\
\hline
\end{tabular}


残留量 $(\mathrm{mg})$ をそのまま粉砕能のパラメータとして用い た.

被検者は下顥両側大臼歯がすべて欠損していて，被検 者 2 と 3 の一側 (NHS) では小臼歯も無く, 犬歯部での 咀鲐を行っていたと考えられるが，下顎犬歯が上額第 1 小歯と嵌合するため, 小四歯部咀緭とみなした.

\section{2. 研究成結について}

1）個人差と咀嚼側差

a. ピーナッッ粉砕能

ピーナッッ咀雺試験結果にあらわれた大きな個人差と 咀嚼側差から, 残存歯数による強い影響が示唆された. Yurkstas (1954) ${ }^{26)}$ によると第 1, 第 2 大臼歯欠損ヶー スにおける咀緭值は $21 \%$ であり，本研究では同じ久損 ケースの咀嚼値の平均值を算出すると $29.1 \%$ となった. また第 2 小臼歯の变失によるピーナッッ篩上残留量の著 明な増加は, Manly (1951)27), Yurkstas (1954, 1949)26, 28)，平沼 (1957) 29) らの報告にみられた事実からよく理 解できる. 見方を変えれば，両側に第 2 小臼歯まで残存 するなら，食物粉砕能はさほど極端には低下しないこと が示唆され，このことは Kăyser (1981) ${ }^{30)}$ の見解とも 一致する.

b. Cycle time

一般に顎機能異常者や咀嚼障害患者では, duration や

Table 17 Means and confidence limits at $95 \%$ level of $\mathrm{CV}$ of burst duration

\begin{tabular}{c|cccc|c}
\hline \hline \multirow{2}{*}{$\begin{array}{c}\text { Chewing } \\
\text { sides (C) }\end{array}$} & WTp & WMm & BMm & BTp & means \\
\hline NHS & 16.34 & 12.40 & 11.86 & 15.90 & 14.12 \\
HS & 16.63 & 13.87 & 13.33 & 15.43 & 14.81 \\
\hline means & 16.48 & 13.13 & 12.59 & 15.66 & 14.47 \\
\hline
\end{tabular}

cycle time の延長 $12,14,16,17,31,32)$ が報告されているが, 本 研究の場合も 5 人平均值でみると NHS では cycle time が延長し，その CV 值も高い值を示して咀嚼の困難性を 思わせたが，個人別にみると必ずしも HS 時に cycle time が短縮するとは限らなかった。このことは大田菌

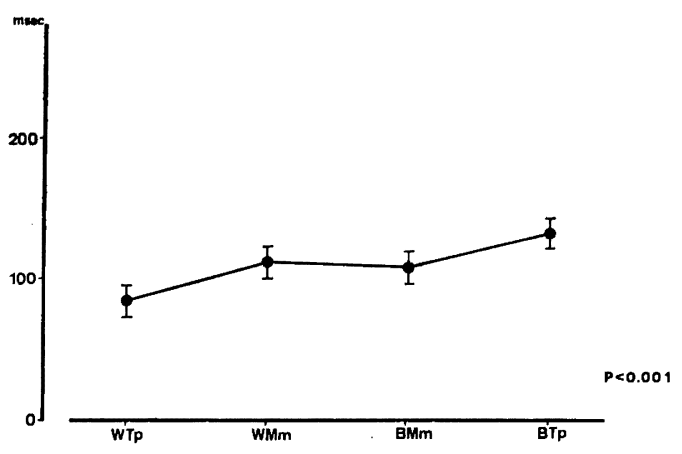

Fig. 10 DOTC. Significant inter-muscle (M) differences in Table20 are illustrated

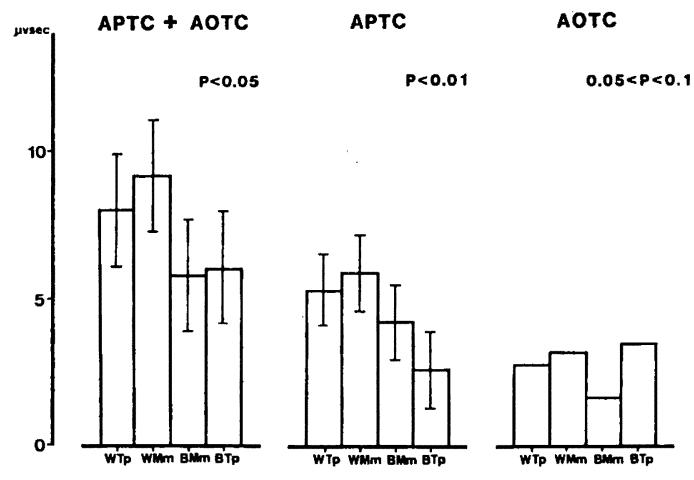

Fig. 11 Integrated EMG activities ( $\mu$ vsec). APTC + AOTC (left), APTC (middle), AOTC (right). Significant inter-muscle (M) differences in Table 8 and 9 are illustrated

Table 18 ANOVAR for DPTC

\begin{tabular}{|c|c|c|c|c|c|c|}
\hline SV & SS & $\mathrm{df}$ & MS & $\mathrm{F}$ & p & $\rho(\%)$ \\
\hline Individuals (I) & 20305.6466 & 4 & 5076.4117 & 5.7144 & $<0.01$ & 22.11 \\
\hline Muscles (M) & 28740.5872 & 3 & 9580.1957 & 10.7842 & $<0.01$ & 31.89 \\
\hline error 1 & 10660.2719 & 12 & 888.3560 & 4.4750 & $<0.01$ & 9.38 \\
\hline Chewing sides (C) & 2935.2256 & 1 & 2935.2256 & 14.7859 & $<0.01$ & 3.10 \\
\hline $\mathrm{C} \times \mathrm{I}$ & 16395.4729 & 4 & 4098.8682 & 20.6477 & $<0.001$ & 17.68 \\
\hline $\mathrm{C} \times \mathrm{M}$ & 6824.9922 & 3 & 2274.9974 & 11.4601 & $<0.001$ & 7.06 \\
\hline error2 & 2382.1756 & 12 & 198.5146 & & & 8.78 \\
\hline total & 88244.3719 & 39 & & & & 100.00 \\
\hline
\end{tabular}


欠損の影響が大きく，特に NHS 時のピーナッツ咀礵試 験で大きい残留量を示したことによっても裹付けられ た.

\section{c. EMG 積分值}

EMG 積分電位が等尺性収縮および一定条件下での等 張性収縮の強さを反映する7,33-36) ことが知られ, Ahlgren と Öwall (1970) ${ }^{7}$ はガムを一定条件下で咀嚼させたと きの咬筋の burst 積分電位と筋張力との間に直線的関係 を認めている. また Körber (1975) ${ }^{37)}$ は, 生物学的に理 想的な咀哷運動を行うための条件の 1 つとして、“調和 のとれた左右側対称的な筋活動”をあげており，Mushimoto \& Mitani ${ }^{22)}$ は正常者のガム咀嗳時におうる両側 咬筋および側頭筋後部の EMG 積分值は，働側咬筋が他 の 3 筋より有意に優勢な coordination pattern を示す ことを報告している.

本研究の被検者別の APTC+AOTC の power coordination pattern をみた場合, 被検者 $3 ， 4 ， 5$ では両側 Tp の積分電位が優勢で, WMm 最優勢の正常パターン がみられなかった ${ }^{23,24)}$ のは，欠損に伴う咀嚼機能障害の 反映と考えられる. 一方, 被検者 1 と 2 においては正常 レベルに近いピーナッッ咀鮞試験成績, cycle time およ びその CV 值などが得られたのは，中心咬合位の安定し

Table 19 Means and confidence limits at 95\% level of DPTC

\begin{tabular}{c|cccc|c}
\hline \hline \multirow{2}{*}{$\begin{array}{c}\text { Chewing } \\
\text { sides (C) }\end{array}$} & \multicolumn{4}{|c|}{ Muscles (M) } & \multirow{2}{*}{ WTp } \\
WMm & BMm & BTp & \\
\hline NHS & 232.44 & 265.44 & 244.15 & 209.97 & 238.00 \\
HS & 252.51 & 239.83 & 233.41 & 157.72 & 220.87 \\
\hline means & 242.48 & 252.64 & 238.78 & 183.85 & 229.44 \\
\hline
\end{tabular}

Confidence limits at $95 \% \quad \overline{\mathrm{M}}_{j}: \pm 20.54 \quad \overline{\mathrm{C}}_{k}: \pm 6.86$ $\overline{\mathrm{C}_{k} \bar{M}_{j}}: \pm 22.71$
ていたことが大きく寄与したためと考えられる，咀嚼側 差ではすべての被検者で例外なく HS 積分值が大き く, 残存歯数の多いこと，および義歯経験のあること， 中心咬合位の安定していることなどの条件差によること が推測された.

2）小田歯部咀嚼の EMG 的特徴

a. DPTC

NHS で BTp の onset time がやや遅れるものの全体 として 4 筋 onset の同期性は高く, chopping 様の咀噢 運動 ${ }^{25,38)}$ の行われている傾向を認めた．またこの際の咬 筋先行型の onset は骨格性下靧前突患者にみられたパタ ーン ${ }^{39)}$ に類似している. 吉村 (1982) ${ }^{399)}$ は下額の閉口運 動を矢状面に投影して 3 級のテコ運動とみなすと，作業 点である歯の咬合接触部までの距離が下頡前突者では正 常有歯額者より長く，力点である下額角部に付着してい る咬筋の負担が増大すると説明しているが，小臼歯部で しか咀嚼できない本被検者群での結果とも符合するとこ ろがある. 一方, HS ではややおもむきを異にし, WTp と WMm に有意差はないが， BTp の遅れが著しく，

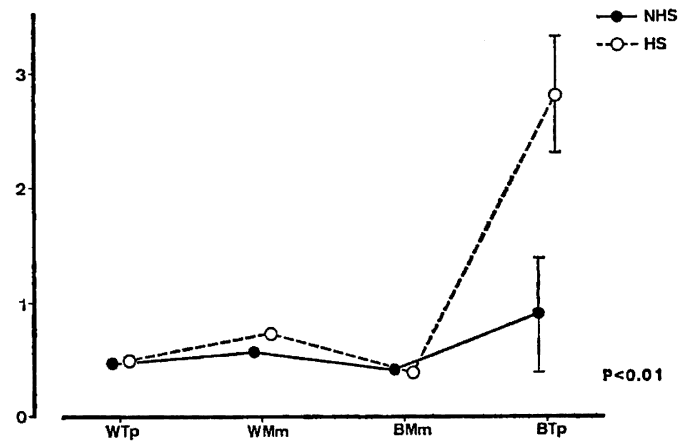

Fig. 12 AOTC/APTC ratio. Significant interaction $(\mathrm{C} \times \mathrm{M})$ in Table 22 is illustrated

Table 20 ANOVAR for DOTC

\begin{tabular}{l|cccccc}
\hline \multicolumn{1}{c|}{$\mathrm{SV}$} & $\mathrm{SS}$ & $\mathrm{df}$ & $\mathrm{MS}$ & $\mathrm{F}^{\prime}$ & $\mathrm{p}^{\prime}$ & $\rho^{\prime}(\%)$ \\
\hline Individuals ( I ) & 33886.4665 & 4 & 8471.6166 & 31.0608 & $<0.001$ & 65.73 \\
Muscles (M) & 6821.4092 & 3 & 2273.8031 & 8.3368 & $<0.001$ & 12.03 \\
error1 & $(4008.9955)$ & $(12)$ & $(334.0830)$ & & & \\
Chewing sides (C) & $(53.0151)$ & $(1)$ & $(53.0151)$ & & & \\
$\mathrm{C} \times \mathrm{I}$ & 1134.4115 & 4 & 283.6029 & 1.0398 & & 0.09 \\
$\mathrm{C} \times \mathrm{M}$ & 1232.5297 & 3 & 410.8432 & 1.5063 & & 0.83 \\
error2 & $(2756.5675)$ & $(12)$ & $(229.7140)$ & & & 21.32 \\
error2 & 6818.5781 & 25 & 272.7431 & & & 100.00 \\
\hline \multicolumn{1}{c}{ total } & 49893.3949 & 39 & & & $(\mathrm{msec})$ \\
\hline
\end{tabular}


grinding 様咀嚼運動 25,38 の行われていることがうかが われた。

\section{b. DOTC}

DOTC には咀嚼側にかかわらず BTp の皘極的かつ持 続的な関与がめだった. このことは大臼歯が欠損してい ても小歯部でなお grinding motion を伴う咀嚼運動 が行われていることを推測させる. Dahlberg (1942) は, 硬化ゼラチンの咀嚼による表面積の増加率を指標と する咀喂試験を行った結果， 曰歯欠損のある人でも咬合 接触点の少ないわりには咀嚼能力は減少していないこと を報告し，これは咀嚼回数の増加によるのではなく，切 蒾を咬断と煍磨様運動にも用いるためと述べており，本 研究の結果と符合する見解である。

\section{c. Duration}

4 筋の burst duration の coordination pattern は NHS と HS で有意に異なり，NHS では両側 $\mathrm{Mm}$ 間に差 があり, HS に比へて咀嚼の困難度の高い NHS で Mm 先行型となる傾向は吉村 (1982) ${ }^{39)}$ の下顎前突者におけ る報告と一致し，作業側，非作業侧ともに $\mathrm{Tp}$ の $\mathrm{CV}$ 值 が $\mathrm{Mm}$ より大きい值を示したのは，この条件下で下額 の stabilizer ${ }^{41 \sim 43)}$ として両側 Tp のデリケートな関与を 必要としたためと理解でき，したがって小臼歯部咀嚼運 動の一特徽と考えられる.

\section{d. EMG 積分値}

Table 21 Means and confidence limits at $95 \%$ level of DOTC

\begin{tabular}{c|ccccc|c}
\hline \hline $\begin{array}{l}\text { Chewing } \\
\text { sides (C) }\end{array}$ & WTp & WMm & BMm & BTp & means \\
\hline NHS & 99.08 & 119.91 & 108.24 & 123.63 & 112.72 \\
HS & 91.33 & 105.48 & 105.73 & 139.11 & 110.41 \\
\hline means & 95.21 & 112.70 & 106.99 & 131.37 & 111.56 \\
\hline Confidence limit at $95 \%$ & $\overline{\mathrm{M}}_{j}: \pm 10.76$ & (msec)
\end{tabular}

被検者別に power coordination pattern をみた場合， $\mathrm{WMm}$ 優勢の正常パターンから異常型にまで広く分布 する結果を得たことから，この種の欠損患者における下 頷位の不安定性が示唆された

e. AOTC/APTC ratio

APTC, AOTC 単独では特徴がみられなかったにもか かわらず, APTC/AOTC ratio に関して HS の BTp が 有意に高い值を示したことは，小正菌部咀嚼運動に grinding motion の要素が多く加味されていることを推 測させ，一方，NHS では筋間に有意性のない chopping motion の特徵38)がうかがわれた。

\section{結論}

下頡両側大曰歯がすべて久損し，犬歯ないし小田歯部 でしか咀嚼できない症例における咀嚼運動の EMG 学的 特徴を明らかにする目的で， 5 人の被検者に習慣性咀喂 側 (HS) と非習慣性咀嗳側 (NHS) でチューインガム咀 嚼させ, EMG 的に検索した. またピーナッツ咀㗂試験 もあわせて行い，っぎの結果を得た。

1. ピーナッッ咀䱨試験, EMG cycle time, 皘分值等 の比較から咀嚼の難易度を推測すると，個人差が著しい ものの残存歯数の少ない咀鮞側において困難度が大きか った.

2. EMG burst duration については, NHS では両側 $\mathrm{Mm}$ 間に差があらわれたのに対して, HS では Tp 間に 差があらわれ, NHS と HS では異なる time coordination pattern を示した. CV 值は作業側、非作業側とも $\mathrm{Tp}$ において $\mathrm{Mm}$ より有意に大きい值を示し,この種の 症例におおる咀噮時に両側 $\mathrm{Tp}$ が特に複雑かつデリケー 卜な関与をすることが示唆された。

3. burst 前半部の持続 DPTC は, NHS では咬筋先

Table 22 ANOVAR for AOTC/APTC ratio

\begin{tabular}{l|cccccr}
\hline \multicolumn{1}{c|}{$\mathrm{SV}$} & $\mathrm{SS}$ & $\mathrm{df}$ & $\mathrm{MS}$ & $\mathrm{F}^{\prime}$ & $\mathrm{p}^{\prime}$ & $\rho^{\prime}(\%)$ \\
\hline Individuals ( I ) & 3.7033 & 4 & 0.9258 & 2.2648 & & 5.18 \\
Muscles (M) & 13.8718 & 3 & 4.6239 & 11.3114 & $<0.001$ & 31.70 \\
error1 & $(5.7424)$ & $(12)$ & $(0.4785)$ & & & \\
Chewing sides (C) & 2.6843 & 1 & 2.6843 & 6.5664 & $<0.025$ & 5.70 \\
$\mathrm{C} \times \mathrm{I}$ & 3.2444 & 4 & 0.8111 & 1.9841 & & 4.03 \\
$\mathrm{C} \times \mathrm{M}$ & 6.5725 & 3 & 2.1908 & 5.3593 & $<0.01$ & 13.40 \\
error2 & $(4.0685)$ & $(12)$ & $(0.3390)$ & & & \\
error ${ }^{\prime}$ & 9.8109 & 24 & 0.4088 & & & 39.99 \\
\hline \multicolumn{1}{c}{ total } & 39.8871 & 39 & & & & 100.00 \\
\hline
\end{tabular}


Table 23 Means and confidence limits at $95 \%$ level of AOTC/APTC ratio

\begin{tabular}{c|cccc|c}
\hline \hline \multirow{2}{*}{$\begin{array}{c}\text { Chewing } \\
\text { sides (C) }\end{array}$} & WTp & Wuscles (M) & \multirow{2}{*}{ WMms } \\
\hline NHS & 0.46 & 0.57 & 0.42 & 0.90 & 0.59 \\
HS & 0.48 & 0.73 & 0.39 & 2.81 & 1.10 \\
\hline means & 0.47 & 0.65 & 0.41 & 1.85 & 0.85 \\
\hline
\end{tabular}

Confidence limits at $95 \% \quad \overline{\mathrm{M}}_{j}: \pm 0.42 \quad \overline{\mathrm{C}}_{k}: \pm 0.30$ $\overline{\mathrm{C}_{k} \mathrm{M}_{j}}: \pm 0.50$

行型で，しかも 4 筋の同期性は高く，骨格性下顎前突患 者にみられるパターンに類似していた。 一方，HS では BTp の onset time が他の 3 筋より有意に達れ，NHS よ りも䀾型傾向の強いことが推測された.

4. 歯牙接触から burst の offset まで (burst 後半部) の持続時間 DOTC については, 咀嚼側による差はみら れず, BTp offset の有意の延長がみられ, burst 後半部 における同筋の積極的かつ持続的な関与が示された.

5. 1 burst 当りの積分值 APTC + AOTC および歯牙 接触時点で 2 分した前半部 APTC の power coordination pattern では，いずれも作業側 2 筋が非作業側 2 筋 より有意に大きいが, WMm 優勢の正常パターンはやや 不明瞭であった.

6. AOTC/APTC ratio では, HS での BTp が有意

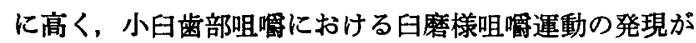
示唆されたのに対して, NHSでは 4 筋間に有意差がな く, chopping 型の運動形式に傾くことがうかがわれた. このことは，非習慣側に拉いて，欠損歯数の多かったこ とも関連があると推測される.

本論文の要旨は第 327 回大阪歯科学会例会（昭和 59 年 6 月 9 日，大阪）において発表した。

\section{文献}

1) Hedegård, B., Lundberg, M. and Wictorin, L. : Masticatory function-A cineradigraphic investigation. Acta. Odontol. Scand., $25: 331 \sim 353,1967$.

2) Watson, R.M. : Masticatory ability-cineradiographic observations. J. Dent., 1:54 60, 1972.

3) Abel, L.F. and Manly, R.S. : Masticatory function of partial denture patients among navy personnel. J. Prosthet. Dent., 3 : 382 392, 1953.

4) Kaires, A.K. : A study of partial denture design and masticatory pressures in a mandibular bilateral distal extension case. J. Prosthet. Dent., $8: 340 \sim$ $350,1958$.

5) Atkinson, H.F. and Shepherd, R.W. : Masticatory movement in the absence of teeth in man. Arch. Oral Biol., $18: 855 \sim 860,1973$.

6) Manly, R.S. and Braley, L.C. : Masticatory performance and efficiency. J. Dent. Res., $29: 448 \sim 462$, 1950.

7) Ahlgren, J. and Öwall, B : Muscular activity and chewing force: A polygraphic study of human mandibular movements. Arch. Oral Biol., $15: 271$ $280,1970$.

8）川畑 衛: 各種食品咀嚼時の咀哷筋の䅡分筋電図につい て, 歯科医学, $32: 453 \sim 486,1969$.

9）豊岡博夫, 佐々木元, 末光哲雄, 棟久信宏, 橋田博文, 長 沢宏道 : 咀嚼笳管電図の規格化に関寸る実験的研究, 広大 歯誌, $6: 17 \sim 24,1974$.

10）小川晴彦：実験的咬合干涉が咀緭筋筋電の時間的要素にお 上ほす影響，歯科医学，39:421 440, 1976.

11）加藤信次 : 䋶関節機能障害患者の切歯点における咀嚼運動 について, 歯科医学, $41: 117 \sim 146,1978$.

12）宮崎 哲：インプラントー粘膜支持型義歯による咀嚼運動 の筋電図学的研究，末発表.

13）西崎 宏: EMG Visual Biofeedback による頇関節症の 治療効果, 補緅誌, $28: 1040 \sim 1062,1984$.

14）太田 宏：䪾関節症患者における EMG 的パラメータの 診断的意義, 歯科医学, $44: 844,1981$.

15）土居 勗：実験的犬歯誘導咬合付与が咀獣運動に及ぼす影 響, 齿科医学, $47: 514 \sim 541,1984$.

16）小柳圭司：口蓋前半部義歯床による咀嚼運動一の影響につ いて, 歯科医学, $47: 184 \sim 224,1984$.

17）川野 晃：下顎床義歯の日歯部舌側フレンジが咀嚼運動に 及ぼす影響, 蒾科医学, $47: 141 \sim 183,1984$.

18）三谷春保：筋電計による咀嚼筋活動の診査, 歯科ジャー十 ル, $16: 307 \sim 313,1982$.

19）虫本栄子：咀噮筋筋電図の記録法と読み方, カラーアトラ ス歯科臨床䛾座, $7: 395 \sim 402$, 医歯薬出版, 東京, 1983.

20）橋本猛伸：日歯補緅の効果に関寸る筋電図学的研究，歯科 医学, $32: 58 \sim 92,1969$.

21）多和伸浩：咀嚼時閉口笳の EMG Coordination Pattern について, 補娺誌, $15: 48 \sim 66,1971$.

22) Mushimoto, E. and Mitani, H. : Bilateral coordination pattern of masticatory muscle activities during chewing in normal subjects. J. Prosthet. Dent., 48 : 191 197, 1982.

23）虫本栄子, 三谷春保：皘分電位からみた咀虂筋の両側性協 調様式, 媨波と筋電図, $8: 78,1979$.

24）三谷春保, 虫本栄子：特に神経筋機構を考虑した症例, 補 
緅臨床，別冊（補䋧の診療計画とその診查）：87 95, 1979.

25）仁科隆実：咀霞運動様式の EMG 的特徵について, 歯科 医学, $42: 1 \sim 27,1979$.

26) Yurkstas, A.A.: The effect of missing teeth on masticatory performance and efficiency. J. Prosthet. Dent., $4: 120 \sim 123,1954$.

27) Manly, R.S. : Factors affecting masticatory performance and efficiency among young adults. J. Dent. Res., 30:874 882, 1951.

28) Yurkstas, A.A. and Manly, R.S. : Measurement of occlusal contact area effective in mastication. Am. J. Orthod., $35: 185 \sim 195,1949$.

29）平沼謙二：咬合面積並びにその咀喚効率に及ぼす影響，補 緅誌, $1: 17 \sim 36,1957$.

30) Käyser, A.F.: Shortened dental arches and oral function. J. Oral Rehabil., 8: 457 462, 1981.

31) Mushimoto, E. : The role in masseter muscle activities of functionally elicited periodontal afferents from abutment teeth under overdentures. J. Oral Rehabil., 8 : 441 455, 1981.

32）前田照太 : 咬合性额関節症の筋電図学的研究, 歯科医学, $43: 229 \sim 267,1980$.

33) Lippold, O.C.J.: The relation between integrated action potentials in a human muscle and its isometric tension. J. Physiol., $117:$ 492 499, 1952.
34) Bigland, B. and Lippold, O.C.J.: The relation between force, velocity and integrated electrical activity in human muscles. J. Physiol., $123: 214 \sim 224$, 1954.

35) Ahlgren, J. : Mechanism of mastication. Acta Odontol. Scand., Suppl. $44: 1 \sim 109,1966$.

36）三谷春保：咀虂筋の筋電図，神释研究の進歩，18：1086 1095, 1974.

37) Körber, K. Zahanärztliche Prothetik. Georg Thieme Verlag, Stützgart, 1975.

38）後藤栄二：咀獣運動様式を意識的に変えた場合の EMG coordination pattern について, 歯科医学, $45: 732$, 1982.

39）吉村 弘：骨格性下頭前突患者の咀嚼運動に関寸る筋電図 学的研究, 歯科医学, $45: 337 \sim 356,1982$.

40) Dahlberg, B. : The masticatory effect. Acta Med. Scand. Suppl. 139, 1942.

41) Sicher, H. : Oral Anatomy. C.V. Mosby Co., St. Louis, 1949.

42) Carlsöö, S. : An electromyographic study of the activity, and an anatomic analysis of the mechanics of the muscle. Acta Odontol. Scand.,10, Suppl. 11 : $1 \sim 132,1952$.

43）河村洋二郎：口腔生理学, 174 184, 永末書店, 京都, 1979. 